\title{
Integral Evangelism as Platform for Christian Spirituality in Context of Africa
}

\author{
Mipo E. Dadang, PhD* \\ Nigeria \\ *Corresponding Author: Mipo E. Dadang, PhD, Nigeria

\begin{abstract}
Integral evangelism as platform for Christian spirituality in context of Africa is at crossroad and at stake today in many Christian cycles. In the area of evangelism or witnessing Christ, it zeal tends to diminish over time. Scholars, Christian leaders, pastors and Christians generally have become concerned with questions of conservative methods. It appears Christians in context of Africa are a lot like the rich young ruler in the Gospel of Matthew. For example, in Nigeria West of Africa alone, if church attendance means anything, it is one of the most devout exercises that cannot be missed every Sunday. The missing connection to integral evangelism is the emphasis on conservative way of doing evangelism among unbelievers. The moment conversion occurs those converts go through some formal theological teaching called "steps to baptism" for few months, then they are baptized. After which the church have them live and practice persistent religious rituals in church. Today, in context of Christianity in Africa, a crucial question concerns how spirituality transmits itself and how it is received across contextual boundaries? If Christians in context of Africa must approach and do evangelism Jesus' way, there is need for the church to return to integral evangelism. Thus, this article discusses integral evangelism as a platform for Christian spirituality in context of Africa with the aim of helping churches and individual Christians return to the practice of gospel proclamation with an integration of evangelism approach that addresses both the spiritual and the physical.
\end{abstract}

Key Words: Nigeria, Integral Evangelism, Christian Spirituality, theology, contextualization, Africa, transformation, Liberation theology.

\section{INTRODUCTION}

For centuries, humans have been drawn to urban cities for perceived economic benefits and as a refuge of last resort. An immigrant seems a broad description. But its general meaning refers to someone who has settled somewhere other than their country of birth. However, Guy Brandon drawing from Old Testament perspective (Genesis 12:1-3 \& Deuteronomy 26:5-11), notes that "Immigrant can be rendered as alien, foreigner, sojourner, or stranger" (Brandon 2011:4).In the New Testament, Peter continues the idea of immigrants by describing Christians as aliens living in a foreign culture with different standards (1 Peter 2:11-12). This is true and fundamental for Christian personal evangelism today, living, moving and migrating with the gospel to a culture that is often hostile to new faith. This type of immigration continues. Immigration has contemporary implication for both Africa context and around the globe as well. Increasing immigration of people across borders is a global and local reality of our times that has significantly impacted humanity in recent years. For example, the "Global Conversation, "jointly published by Christianity Today International and the Lausanne Movement in the months leading up to Cape Town 2010(which I was a part of the selected African leaders who participated in the planning), gives a historic break down that "since the 1960s, human migratory flows have remained at historically unprecedented levels due mainly to decolonization, economic globalization, global demographic trends, environmental disasters, armed conflict and political upheaval". The report further explained that "By 2005, UN estimates, that one in every 33 persons on the planet (a total of roughly 192 million people) was an international migrant". For majority of the people, movement is a matter of survival. In Nigeria, West Africa, for example, a major migrant group is internally displaced persons (IDPS) displaced by violence as a result of Boko Haram and or ethnic conflicts or even within the country. A lot of people from the north east of Nigeria have been displaced becoming migrants in their own homeland. Majority of those internally displaced persons are women and children travelling to places that are less vulnerable in search for new life. For years now, some of them have become victims of torture, rape and extreme deprivation. 
It has since been on world record that the whereabouts of the Chibok Girls kidnapped has been a tale. Another pathetic victim was the kidnapping of Leah Sharebu a Christian girl that up till now has not been reunited to her parents. In 2008 alone, the internally displaced persons numbered 26 million, with the majority in Africa. The lines between international migrants and internally displaced persons are often blurred in the developing world. Sadly, the vast majority of migrants are non-white and nonwestern. Apart from the plight of migrants which is global, this has been compounded with the vast array of electronic media much of which originates in the cities, and rural areas. Escobar notes that "migrants from poor countries who travel in search of economic survival carry the Christian message and missionary initiative with them" (Escobar2003:66). This call for advocacy in favor of integral evangelism by every missionary and or very Christian in context of Africa today.

\section{Statement Of The Problem}

Since era of early missionary work to Africa, the idea of evangelizing Africans tended to be more on individual basis. The meaning of conversion to salvation for these early missionaries was then the salvation the salvation of the soul and not the body. For example in Plateau, Southern Kaduna and the entire Middle Belt where Boko Haram and armed Fulani Herds have made the entire region more devastated and impoverished than ever today. This has happen so today because early missionaries stopped indigenous Christians who were converted to Christianity from studying law, medicine, agriculture, business, political science and participation from politics; economic empowerment and a host of others were considered evil because salvation to these missionaries only the forgiveness of sins. This early missionary approach to evangelism omitted integral mission. But a careful study and understanding of salvation in the Bible suggests evangelism that leads to salvation is holistic. It is evangelizing people to have shalom of both the body and soul. This article calls for redefining the meaning of evangelism to help Christians contextualize the gospel message with an integral approach in context of Africa. This contextual approach argues by Taber (1983:119), "is the attempt to take the concrete human context in all its dimensions with utmost seriousness. The particularity of each milieu becomes the starting point for both the questions and the answers which will shape the evangelistic process and its aftermath in the life of the new church."

\section{Perspectives On InTEgral Evangelism}

There are several spectrums of perspectives on evangelism which include from practical to theoretical, conservative to liberal and fundamental to historical critical hermeneutical articulation of evangelism in contexts of humanity. When contemporary people ask about the value of evangelism what criteria does a person employ to explain? The confusing theories provides room for various theologies plagues the academic study of evangelism as well. It is further difficult in the field of evangelism as too little attention has been given by certain scholars. Tucker (1983:114), notes that "many if not most eighteen century church believed that the Great commission was given only to the apostles and therefore converting the heathen was no concern of theirs especially if it were not tie to colonialism."Adeney (2000:282,283) noting from an American point of view states that "selfdesigned spirituality of American recognizes that spirituality is a legitimate area of need and a conversion may be profoundly felt but transient." Adeney (2000:283), further explains that "since religion is individual, it is poor form to intrude one's religion on others unless they ask about it. A person may share his or her story but should not push others to follow.'Tucker (1983:115), narrated the experience of William Carey that he conveyed his idea to a group ministers on the need to reach out to those in need of the gospel that would lead them to Christ. But one of the ministers retorted. He replied Carey saying, "Young man, sit down, when God pleases to convert the heathen, he will do it without your aid and mine." However, Carey refused to be silenced about the matter of evangelizing the heathen world. While there may still be possibility to find certain scholars in modern society who still hold on to the notion of not being committed to evangelism as in the days of Carey. Biblical missiologists argue on the need for evangelism who help in clarifying the importance of evangelism through which its theory and practice are mutually informed in contexts of humans. For example, Bakke (1987:145) argues that "evangelism $n$ various contexts is the news of Christ which transforms the climate and gives people hope." Stewart (1994:14) affirms that "careful study of cultural contexts is absolutely critical to effective practice of evangelism." Thus there are fundamental Issues in evangelism.

\subsection{Fundamental Issues for Practice of Integral Evangelism}

Bosch (1991:15) argues that "the New Testament is a thoroughly missionary documents." Bosch understands evangelism as an essential part of mission which is primarily witness but aims at a 
response. It is not church growth, neither is it disconnected from it. Authentic evangelism is always contextual and cannot be divorced from the preaching and practicing of justice. Aside from the idea of Bosch, Abraham offers deepest and fascinating concept on evangelism that focuses on God's kingdom which is the heart of the gospel. Abraham (1989:95) argues that "we can best improve our thinking on evangelism by conceiving it as that set of intentional activities which is governed by the goal of initiating people into the Kingdom of God for the first time."Abraham (1989:95), explains that the initiation has six components which are Christian life, conversion, baptism, morality, the creed. Spiritual gits and disciplines." Abraham's view seems fundamental in a sense that it is not sufficient for someone to experience the new birth emotionally, if they are not taught the basic doctrines of the Bible as contained in the Nicene Creed. Theologically, the creed as recited in the universal church worship reads, "I believe in God, the Father Almighty maker of heaven and earth. And in Jesus Christ His only Son our Lord who was conceived by the Holy Spirit, born of Virgin Mary, suffered under Pontius Pilate, was crucified, died and was buried. He descended into hell. The third day He rose again from the dead. He ascended into heaven and sits at the right hand of God the Father Almighty from where He will come to judge the living and the dead. I believe in the Holy Spirit, the holy Christian Church, the communion of saints, the forgiveness of sins, the resurrection of the body, and the life everlasting, Amen."

Thus theological depth and holistic approach to Christian life is the foundation for evangelistic practice. Costas (1989:10, 31), argues that "evangelism is a communal activity. A Trinitarian concept God chose for transformation of the world. Thus evangelization is liberating news that is prophetic and apostolic." Klaiber (1997:199) notes that "evangelism is preaching the message of salvation."Hunter $(1996: 19,20,21,22,23,24)$ believes that evangelism takes place when missionaries "reach the unchurched persons. Their theologies center on the gospel of early apostolic Christianity by adapting the language of their target population."Brueggemann (1993:14), states that "evangelism is inviting persons to abandon other stories and instead live out the biblical stories to define their lives."Therefore, for an evangelist to have an effective evangelism in contexts of people, requires that the gospel is presented across cultures.

\subsection{Integral Evangelism in Contexts}

In order for the gospel to move across cultures, Walls (Walls1996:26), notes that "it involves a translating principle."The missionary is to become familiar with the process. It is a process through which the Gospel becomes incarnate in each new tradition into which it goes. Walls (Walls1996:26), further explains that "in the light of the frustrations inherent in the translation process, it is more astonishing that God chose translation as his mode of action for the salvation of humanity." Christian faith rests on the divine act of translation because the Word became flesh and dwelt among human (John1:14).Walls (1996:26), alleges that "any confidence we have in the translatability rests on that prior act of translation. There is a history of translation of the Bible because there is a translation of the Word into flesh."Understanding Walls correctly, the text moves into a new context. This process is at work already in the New Testament as the gospel moves from the Jewish to the Gentile. Evangelism therefore, does not only involves taking the gospel to cross-ethnic groups but includes the clear understanding in the process of contextualization.

\subsection{Integral Evangelism in Contextual Process}

Stott (1997:21), notes that, "Culture is an integrated system of beliefs either about God, reality or ultimate meaning of values about what is true, good, beautiful and normative of customs."Stott(1997:21) believes culture includes "How to behave, relate to others, talk, pray, dress, work, play, trade, farm, and of institutions which express these beliefs, values and customs, government, law courts, temples or churches, family, schools, hospitals, factories, shops, unions, and clubs which bind a society together and give it a sense of identity, dignity, security and continuity." Therefore in advocating for the need for contextualization, Taber (1983:119) notes that "the missionary process may be understood better starting from a distinctive understanding of the Bible, the word, the sending church and the receiving context." Taber (1983:119), stresses "if this understanding is narrow, we have a narrow missiology that can be paternalistic (that is old evangelical), worldly (that is liberal), or socially conservative (that is church growth).'Taber (1983:119) concludes that, "The contextual approach is the attempt to take the concrete human 
context in all its dimensions with utmost seriousness. The particularity of each milieu becomes the starting point for both the questions and the answers which will shape the evangelistic process and its aftermath in the life of the new church." Newbigin (1995:7), upholds that fact that "evangelism can be better approached if every proposed expression of the church's missionary outreach is tested by asking whether it can be accepted as an authentic expression of the gospel." Snyder (2001:224), balances it noting that "the gospel is good news about personal, social, ecological, and cosmic healing and reconciliation. It is God's good news to the whole creation and to the whole cosmos."From Snyder (2001:224), further affirms that "the gospel is good news to people, nations, and or tribes. It is good news personally and socially and to nature itself. It is good news globally and locally. It good news personally and socially. It is good news for time and for eternity." Thus for evangelism to take roots in any context it requires for essential tasks. (1). Evangelism should lead to planting new churches. (2). Newly converted people to Christianity be nurtured to maturity within these churches. (3). Local leaders are to be trained to evangelize in their own context. (4). There is the need to empower the new community of faith to become self-sufficient to embrace Christian growth. Therefore, planting new churches, maturing ne Christians, training leaders and empowering them to become viably self-sufficient any context where new believers are brought to salvation in Christ require Strategic Biblical foundations on how they are planted.

\subsection{Biblical Framework for Integral Evangelism}

Throughout my years in theological education, I have come to defined Church planting as initiating reproducible relationships that reflect the kingdom of God in the world. A number of characteristics for church planting can be drawn from the definition. First church planting is done for creating relationships. Paul and Peter explain the church as the family of God, the body of Christ and a people belonging to God (Ephesians 1:23; I Peter 2:9). These Biblical images indicate the church must become a cohesive entity in reflecting the qualities of God in an alien world (I Peter 2:11-12). Evangelistic methodologies are not to scatter contacts that are being modelled into the body of Christ. New Christians are not to be treated merely as individuals but incorporated in the body of Christ. A farming illustrative image to explain why new Christians are to work towards becoming a functional relationship is a proverbs many use in central Nigeria. They say, "A tree cannot make a forest." Meaning no matter how well talented a person is there need for such a person imbibe team relationship in order to accomplish a task. Likewise, an individual cannot be the church alone. Other members of the body in Christ are needed to work together to build a functional relationship. McGavran (1990:7), counsels that "would be disciples must be joyfully built into his body. They must not wonder alone in the wilderness."McGavran (1990:7), argues that, "New converts are led to the Lord and then left before a congregation of believers may come into existence. These few Christians may likely fall away from God because they have not been incorporated into is, relationship which can mould and guide them into their spiritual journey."From Biblical perspective, church planting focuses on cultivation reproductive relationship. I have observed around many churches around Jos, Nigeria that many times churches are established immediately after baptism and accepted into membership without expecting the new Christians to have the ability to teach others. They become single trees that cannot team up to reproduce. They are like seedless grapes that are delightful to taste but without reproductive power. They may be compared to the fig tree which Jesus withered because it did not bear fruit (Matthew 21:18-19). When new Christians are not matured to become intentional reproducible Christians who will mature others, terminal churches are planted.

\subsection{Terminal Churches Results from Non-Integral Evangelism}

Terminal churches may have spiritual vitality but can only reproduce their kinds arithmetically. Broom illustrates a terminal church. Broom (Broom 1976:88), notes it in the following words that, "Ten missionaries can only plant one church each year. If the churches they plant have terminal life, after ten years their field will have 100 churches. If missionaries die or return home, the number of churches static because they do not plant other churches." Broom (1976:89), continues that "The same ten missionaries by planting churches have 5,110 churches in their field. If the missionaries die or return home, the churches will continue to multiply because they have germinal life."From Biblical point of view, once Christian communities develop sufficient roots in new Christians by planting still other viable fellowship centers a strong cell group immerge. Paul encouraged Timothy to encourage his new Christians to become reliably responsible reproducible Christians. Paul said, "The things you heard me say in the presence of many witnesses, entrust to reliable people who will also be qualified 
to teach others" (2 Timothy 2:2). This method of reproducible principle happened among the Boko people in Africa. The first church that was established in collaboration with the native of Boko people. The newly converted Christians were discipled to bring them to maturity in Christian faith. After a period of time, they were allowed to become part of the missionary team. They were allowed to interpret the gospel to their fellow natives in their own mother tongue. They also said prayers in their own native tongue.

It became an amazing story that after six years of missionary work, the native Christians reproduced themselves and planted 35 viable new churches. After another two years, the first area in which 9 churches were established became the central headquarters for missionary activities to other places that were unreached. This growth was rapid because Christian activities were done in context of their mother tongue. This is what germinal growth is all about. They prayed, teach, worship, sang, and witness to their unreached neighbors in their own local language. This was how contextualized evangelism resulted to a healthy church life. Danny McCain(key note address, 1999:3), described this well in a paper he presented in Jos, Nigeria that "Contextualization includes many different aspects of church life, including the style of worship services, kinds of church government, methods of evangelism and various lifestyle issues."McGavran (1990:321), affirms that, "The web counts tremendously. Every person knows and is intimate with not only brothers, sisters, and grandparents, but cousins, uncles, aunts, great uncles, sister-in-law, mothers' in-law and many others. Members of other clans or families can become Christians and remain unmoved." Hestenes (1983:11), notes that "the Christian life is not a solitary journey. It is a pilgrimage made in the company of the committed." Hestenes' thinking may be illustrated with a model of evangelism adopted in Bokoland, North central Nigeria which always targets a specific ethnic group who live in a homogeneous unit. Boko people typically live in a large extended families that know everyone in their village. Contact for evangelism flow principally along kingship and family linage. Missionaries used it as a framework to build on their ethnic foundation to develop a model along four stages: (1).The initial church stage is considered an introductory evangelism phase wen people were converted to Christian faith. At this point the new Christians are hardly a group. They are considered like newly born babies who did not know how to walk. This stage took about four weeks to six months depending on the receptivity of the people within the village. The joy of this first stage is that a congregation was born through public and private proclamation of the gospel. The second stage is introduced to incorporate the young Christians into a body. (2).The maturation period of these young Christians was called the developing church stage. During the second stage the young Christians are mentored to become reliable and responsible reproducible through cognitive and experimental teaching. The resource person functions as a mentor who develops each member within the body. The matured believer plays a mentoring role by spending one or two days each week visiting from house to house strengthening the new Christians. He holds evangelistic education through meetings to train them. This stage takes six to seventeen months depending on how quick new Christians mature as a body of Christ. (3). This is the independent church stage in which the founder allowed local leaders to be incorporated into a congregation to assume leadership roles. The church is able to stand alone independent of the founding missionary. Finally, the matured church stage was a period of maturation after which intense leadership training had taken place. Elders were elected to pastor the flock. Evangelists were set aside to lead congregations to proclaim God's redemptive message in the local village. Sunday school teachers and other leaders were selected to lead. Newly converted to Christianity were taught to model the life of Christ. As they articulated Christian themes so that the new Christians were eternally rooted in God.

Posterski (1989:15) describes those who built the young Christian into maturity with high words of appraisal. Posterski notes that "makers are people who reside in today's world revealing with their living and their lips that Jesus' death is the source of vital life." Neighbour (1990:21, 22, 23), stresses that such people "holds members accountable to God and equips the laity to testify and proclaim the message of Jesus Christ the context of intimate community of faith." Obrien (2001:24), also notes that "commitment to word and deed missions is combining the proclamation of the gospel in all possible ways with action of love, compassion, and justice and clarify the word." O'Brien believes that "these are inseparable dimensions of the one gospel. In the cause of Christ and the kingdom, they must never be divorced and made to stand alone."Newbigin (1987:11), on the one hand alleges that "words without deeds are empty, but deeds without words are dumb." Thus, evangelism without a commitment to whole gospel, whole persons for whole world mission calls for use of all spiritual gifts 
evident within the body of Christ. Hence it involves the spirit of empowering new believers in Christ to be self-sufficient in all aspects of their livelihoods. Wakatama (1999:40), argues that "Christian business people could assist them with capital and know how so that they would be in a position to support their own ministries."Sider $(1999: 53,54)$ sums up that "the ability to create wealth is a gift from God. God works. God incarnate was a carpenter. Even before the fall God summoned Adam to cultivate the earth and name the animals." Indeed, the concept of self-empowerment of new Christians an important Biblical theme for wholistic evangelism and for church growth. But to understand fully its context in of Christian faith, Christian spirituality as a platform for Christian growth is further discussed. However, first, what is spirituality?

\section{UNDERSTANDING SPIRITUALITY}

Spirituality is derived from Hebrew ruachmeaning spirit, breath, wind and that which gives life and animation to something. McGrath notes that "Spirituality arises from a creative and dynamic synthesis of faith and life, forged in the crucible of the desire to live out the Christian faith authentically, responsibly, effectively and fully,"(McGrath 1999:9). From this idea, spirituality animates a person's life of faith and moves a person's faith to greater depths and perfection. Thus, Christian Spirituality is the quest for a fulfilled and authentic life that involves taking the beliefs and values of Christianity and weaving them into the fabric of life. Spiritual life therefore involves the whole person, body, mind and soul, place and relationships in connection to the whole of creation throughout the era of time. The word spirituality has been jeopardized in today's society both without and within religious circles. This appears so because the idea is often times hard to coin a precise meaning. Simply because it has usually been dichotomized from traditional religious beliefs and practices particularly from its Christian foundations. Human beings are by nature driven by strategic goals and objectives that are more than mainly a desire for material success, physical well-being or even intellectual achievement. Spirituality in its wider concept concerns human nature to a large extend. Evelyn Underhill notes that "Human beings are vision creating beings rather than merely tool-making animals." Underhill $(1993: 16,17)$.Putting it differently, human beings are by nature moved by goals that are more than merely a passion for material progress, meeting physical needs and or mental fulfilment. When it comes to Christianity, spirituality has a more comprehensive concept rather than its general meaning in today's usage. Particularly, it incorporates ways in which people values, livelihoods and spiritual disciplines aim at understanding God, human identity and the desire to transform the cosmos. Today's understanding of spirituality does not only tie to spiritual disciplines. It also has a framework of values that is usually hidden rather than outwardly directed at internal lifestyle. In contemporary spirituality literature, it portrays approaches that concerns what is holistic. It applies an integrated approach to life which is motivated towards the divine. Thus, spirituality seeks to engage life as a whole rather than just a fraction of life. Spirituality involves a search for the sacred. It involves a thirst for meaning and purpose. This can also lead to a search for a meaning to an understanding of personality development. An example of spiritual development is stated in Christian education curriculum of ALPHA, Nigeria. Here, spirituality is defined by Naomi Baba (2016:3) as "the development of the non-material element of a human being, which animates and sustains us." Baba (2009:4), further notes that it concerns "the development of a sense of identity, self-worth, personal insight, meaning, and purpose. It is about the development of a pupil's 'spirit."It involves a thirst for meaning and purpose. This can also lead to a search for a meaning to an understanding of personality development. Spirituality is always tie to an idea of lasting impact that is deeper than simply being successful. Spiritually, to last is to grow or expand as human growth maturity. Therefore understanding spirituality deals with a search for higher values beyond wealth acquisition approach to life. Spirituality also overlaps in significant ways with ethical behavior and moral goal.

\subsection{Theological Framework for Spirituality}

The concept of spirituality emerged in Christianity. Scriptural evidence shows that a spiritual person was mainly someone who lived under the control of the God's power (1 Corinthians 2:14, 15).Christian spiritual traditions are equally rooted in the Jewish and Christian scriptures. These are especially seen the teachings of Jesus Christ in the gospels of Matthew, Mark, Luke and John. Michael de Certeau (1997:142), notes that Christianity implies a "relationship to the event" which inaugurated it: Jesus Christ. 
It has had a series of intellectual and historical social forms "faithful to the inaugural event": the necessity of being different from these beginnings. Imbedded in Christian scriptures is the Hebrew Bible. Apart from the reality that Jesus and his first disciples were Jews, the Christian scriptures grow out of the Hebrew Scriptures in various ways. Also, the Hebrew Scriptures have had a significant impact on Christian spirituality over two thousand years from the use of the Psalms in Christian worship and the Song of Songs. In the light of Psalms and Song of Songs, Anton Baumohl (1984:17), argues that "The Old Testament provides repeated evidence of God's concern for the social, political, and economic livelihood and political aspects of life." Baumohl (1984:17), elaborates that "Lives in both the Old and New Testaments reveals how a relationship with God touches on every aspect of individual's being, physical, emotional, psychological, intellectual, social and spiritual." Therefore the main New Testament picture for the Christian life is discipleship. Christian spirituality is therefore not reducible to devotional practices or to theoretical theory. It has a complete way of life. Interestingly, discipleship is constantly expressed in the New Testament by the use of the Greek noun mathetes. This refers to a person who learns. But this learning does not end within cognitive domain. This implies not simply a teacher-student relationship between Jesus and his disciples. But it also implies that the Christian disciple absorbs a whole way of existence by being alongside the teacher. Afterwards, the disciple is left alone to reproduce others to make them become disciples who will reproduce more disciples through multiplication rather than addition. This connects the concept of discipleship to another important verb in the New Testament which is akolouthein: to follow, or follow after. However, the biblical idea of discipleship is more than mere following of a teacher. Anton Baumohl (1984:17), explains that "Being God's people or follower of Jesus is never portrayed in the Bible as a separate dimension tolife but is clearly seen as encompassing the whole of life." This concept of discipleship has three elements to be desired. (1). It is call to conversion. That is to turn away from previous flawed ways of sinful behavior in response to a call from God. Mark (1:15), records Jesus' speech as saying, "The time is fulfilled, and the kingdom of God has come near, repent and believe in the good news." (2).After conversion is to actively follow the way of Jesus. This involves both a new way of life and joining in the building of the kingdom of God. Greg Ogden (1990:44), believes a converted person is one "Whose life is created by and dependent on the living Christ."

From New Testament account, a converted person continue with the mission of Jesus. Jesus clearly explained this when he said, in Mark(1:17; Matthew 4:19) "And Jesus said to them follow me and I will make you fish for people." This same call to repentance and to following the way of Jesus is presented at the beginning of Jesus' ministry in the Gospel of Matthew 4:17). (3). Involves reproducible principles of discipleship (Matthew 28:19-20). Despite the fact that discipleship is expressed differently, it is implicit in the Gospels of Luke and John. It is further recorded in the New Testament that Jesus chose his own disciples (Mark 1:16-20; Matthew 4:18-22; Luke 5:1-11; John 1:35-42). This shows first that discipleship is a response to a call. Second, the title discipleship is not given because of social status or some sort of religious superiority. Jesus is recorded as calling despised tax collectors (Matthew 9:9). He called all kinds of sinners or socially marginalized people (Mark 2:15-17). There were also women at Jesus immediate circle (Luke 8:1-3). However, Jesus called upon everyone to repent and to welcome the kingdom of God. Yet, Jesus call people to join him in formal discipleship was only made to those who were faithful, available and teachable.

Third, the call to discipleship signified a radical break with the past that involved leaving everything for the sake of Christ's gospel (Luke 1:26; Mark 10:21; Luke 5:11). The cost for that radical change was sometimes characterized by losing one's life in order to find it (Mathew 10:38-39). Willimon (2000:116), affirms that "All disciples are commanded to take up the cross to throw away life for the sake of the Gospel." Fourth, the call to discipleship shows involvement in bringing about God's kingdom through a process of reproducible multiplication. Hence, Bennell (2001:44), notes that "Evangelism and discipleship must be seen as integral." If people are evangelized, they need to be discipled to holistic growth. Ogden (2003:16) argues in favor for contemporary application of discipleship. Ogden notes that "Disciple making, discipleship and discipling are hot topics today because we see such a great need for this focus in our churches." Hull (1988:14) further argues that "The crisis at the heart of the church is a crisis of product." Hull (1988:19), cautions that "Choosing to be a self-sufficient and selfish Christian is choosing to live a spiritually anaemic and impoverished life." Ogden further argues "A person is a converted one who whose life is created by and dependent on the living Christ" (Ogden1990:44). This means evangelism and discipleship must be integral for 
spirituality to become whole. That is why being God's people or follower of Jesus is never portrayed in the Bible as a separate dimension to life but clearly seen as encompassing the whole of life. It is in the light of the forgone that Baumohl (1984:17), notes that £The Old Testament provides repeated evidence of God's concern for the social, political and economic livelihood and political aspects of life." Baumohl(1984:17), further emphasizes that, "Both the Old and New Testaments reveal how a relationship with God touches' every aspect of individual's being ,physical, emotional, psychological, intellectual, socially and spiritually."Foster (1998:29), notes that "Christians throughout the centuries have spoken of a variety of ways of listening to God" to improve their spiritual lives. What then is the relationship between spirituality and beliefs practices?

\subsection{Spirituality and Beliefs Practices}

As already explained, Christian spirituality has an understanding of God', the material, and human identity. Putting it simply, Christian spirituality and beliefs cannot be separated. However, as it would be noted the study of Christian spirituality would reveal how the relationship between beliefs and spirituality has changed over time. Basically the various traditions of Christian spirituality grew out of spiritual practice rather than out of theory. That is the more reason why formal meanings of Christian doctrine about God; Jesus Christ as both human and divine, did not come from intellectual brain storming. They grew out of the ways in which members of the early Church sought to live in closed relationship to Jesus' life and teachings as expressed in the New Testament. That was not all, but they experienced his abiding presence with him. Christian doctrine, scripture, and the Christian life were intimately interconnected. However, the motives behind seeking greater doctrinal precision grew from a sense that authentic living depended on maintaining right biblical standard and belief that led to spiritual authenticity. It was not surprising that Christians came to see that being clear about the nature of Jesus Christ, and his relationship to God, was critical. The doctrine of the Incarnation, affirming that in the person of Jesus of Nazareth there was a union of the divine and the human, not only governed all other Christian beliefs but was also the bedrock of Christian spirituality. Irenaeus of Lyons, (c130-200), who was a major thinker and a bishop in the Roman province of Gaul affirms this. Alexander Roberts and James Donaldson(1994:325), notes that Irenaeus testified saying "The Word of God did become what we are, that he might bring human to be what he is Himself." Irenaeus contended against a heresy called Gnosticism which comes from the Greek word knowledge (gnosis).

This heresy had two implications. The first was an emphasis on esoteric knowledge. That is true knowledge of God was reserved to a special group of initiates who inherited secret oral teachings. The second implication was that his secret knowledge involved a dualistic anti-material beliefs. Therefore such teaching culminated in an erroneous view that the bodily human existence is a result of sin. According to this view, humanity have a fundamental spiritual nature that is trapped in the body and belongs to another world. So it needs to return there. For a biblical Christian, such an understanding undermined Scriptural position of the truth that God actively created human embodiment. It further distorts the biblical position that God entered the material world and into the human condition in the person of Jesus Christ. The process of clarification about the nature of Jesus Christ and his relationship to God and implication for Christian faith dragged for several hundreds of years to formally defined and treated. Two official Councils of Christian leaders stand out. The first was the council of Nicaea in 325 condemned the heresy of Arianism which was named after an Egyptian priest called Arius. Arianism denied that the nature of God could not be shared or communicated. Therefore Jesus Christ was not an uncreated equal of eternal God as the Father. This heretic ideology suggested that there was no equal intimate relationship between God and humanity. It was against this unbiblical theology that the famous Nicene Creed that came to be recited in Christian worships affirmed that Jesus Christ is "God from God" and of One in essence with the Father. Another heresy that led to calling the council of Chalcedon in 451 condemned the opposing view that Jesus was only divine and not fully human at all. This heresy was named Monophysites. The theory undermined the value of human condition of Jesus Christ. The Chalcedonian creed upheld and affirmed that Jesus had two natures as truly God and truly human. At the end of all the debate about doctrine there was understanding which led to Christian life and particularly to the understanding of the nature of human life more correctly. It has been discussed that Christian spirituality is built upon discipleship. Therefore the understanding of Jesus as truly God and truly human builds a background to discuss Christian spirituality as transformative mission.

\section{Christian Spirituality and Transformative Mission.}

This position is clearly explained in the Gospels as the main task of extending Jesus' proclamation of God's kingdom to the whole universe as demonstrated in (Matthew 28:18-20; Mark 16:15 and Luke 
24:46-49). However, taking it simply as only a call to proclamation of the kingdom as a verbal communication of information about God or of moral teachings is not comprehensive as such taking the passages into their entire contexts, it equally means proclaiming the way of Jesus from its beginning was understood as living after the manner of Jesus' Christ. Thus, Christians extended Jesus mission by being a living message through the kind of people they were and how they acted in the world (Matthew 5:13-16; II Corinthians 3:3). However, while later forms of Christian spirituality reinterpreted these scriptural foundations it is possible to affirm that personal transformation and the mission of transforming the world are two key motifs. The history of Christian spirituality is a rich and varied commentary on those two motifs has been expressed in a broad variety of spiritual journeys and literature in view of these values, all classical Christian spiritual traditions address certain fundamental questions either directly or indirectly. First, with regards to personal and social transformation what needs to be transformed and why? In the second instance, is transformation mainly individual or does it transform a society? Thirdly, what factors stand in the way of transformation? These factors were described in religious terms. But today's scholars also bring to consideration psychological, social and cultural factors.

Fourth, what is the context of transformation in relation to personal evangelism and Christian spirituality? Is it the processes of everyday life or does it demands stepping aside into a special context such as the desert, monastery, or a retreat home? Fifth, how does transformation occurs? Does it involves certain theories about spiritual growth takes place as well about lifestyles or spiritual procedures that support it? Sixth, what is the purpose of transformation? To put it another way, Classical Christian spiritual traditions offer vision of spiritual enlightenment and human completeness. Thus in the light of the word mission, the perspective is both acceptable and argumentative. For some Christians, mission has a proselyting implication. That is converting people to Christian faith is proselyting. For others Christian mission focus is an outward way of looking. That is to say a key part of Christian life is to share in God's own mission to make a better world of proclaiming his creativity, active goodness, and reconciliation which leads to love directed towards making humanity to arrive at its ultimate destiny. Putman (2010:37) notes this act of combined mission approach includes "hands-level mission when Christians are committed to the mission of Christ." This outward look seeks to respond to the lives and needs of others. It expands the concept of mission beyond religious preoccupations and embraces social transformation. Thus, it has implication for integral mission. It lays emphasis on Jesus' message which made the disciples attended to the needs of the poor and marginalized spiritually and physically to make their voices to be heard (Luke 4:18). Thus, Klaus Detlev Schulz (2009:301) makes a passionate appeal that "The church must learn to listen to the cries and the crises of our time." Perkins (2001:21), equally argues that "The gospel rightly understood is wholistic. It responds to people as a whole people. It does not single out just spiritual or just physical needs and speak to those."Transformation mission can be discussed in the light of images of spiritual transformation.

\subsection{Images of Spiritual Transformation}

At this stage it is foundational to offer a summary on classical approaches to spiritual transformation. A significant image in Christian spirituality is pilgrimage image or journey. Thinking of a journey, Paul draws attention by showing his readers that Christian trait portray Christians as belonging to heavenly citizenship (Philippians 3:20). Spiritual pilgrimage was an important motif in classic literature from Augustine's City of God by the $5^{\text {th }}$ century to John Bunyan's Pilgrim Progress during the $17^{\text {th }}$ Century. The theology of the early church gradually developed a practice of successive stages on spiritual pilgrimage. For example, Origen wrote three ascending stages away from material existence towards a "greater transcendent light and the perfect" (Greer 1979:45). The goal was to recover the original created likeness of God in the soul. However, while Christian approaches to spiritual pilgrimage may offer wisdom for the contemporary day, such individual approach can be balanced by a renewed biblical emphasis on cooperate social understanding. For example, the Second Vatican Council of the Roman Catholic Church in the early mid-1960s underlined that it is the Christian community as a whole that is a pilgrimage people "led by the Holy Spirit in their journey to the kingdom of their Father." Sadly, this recovery of a cooperative understanding of spiritual journey propelled the subject of radical solidarity with others in the movement called "Liberation theology." Palmer (2015:173), notes that "Liberation theology is concerned with the contemporary realities of poverty and political oppression." Hence, engaging Christian Spirituality with only the sole aim of 
transforming society appears lopsided. All people are equal in God's eyes and therefore both the poor, marginalized and the non-poor need to rediscover their real identity as originally created in his image and living in the presence of God( Romans 12:2).

Thus spirituality that leads to total transformation addresses man's want of original righteousness and of holy affectedness toward God and the corruption of his moral nature and bias toward evil is called depravity. The extent of depravity is that human nature is wholly depraved. It does not mean that every sinner is the worst sinner that he can be. It means that every sinner is totally destitute of the love of God which is fundamental requirement of the law (Genesis 6:4ff; Matthew 22:37; Romans 8:7; Ephesians 4:18). Depravity has produced total spiritual inability( Jeremiah 17:9; Mark 7:21-23), in the sense that he cannot by his own volition change his character and life so as to make them comfortable to the law of God; nor change his fundamental preference of self and sin to supreme love for God. Penalty for man's sin results in first of all Physical death which is the separation of soul and body (Genesis 2:17; 3:19; Romans 5:12-17). The next is spiritual death is the Separation of the soul from God (Ephesians 2:5; Romans5:21), leading toeternal death as the culmination and completion of Spiritual death. It is the eternal separation of the soul from God (Matthew 10:28; 25:41). Thus integral evangelism which leads to Christian spirituality should lead to holistic shalom in humans.

\section{CONCLUSION AND RECOMMENDATION}

Integral evangelism as a platform for Christian Spirituality has extended and given room for a reflection on Christian life in the everyday world. Its study involves material beyond literary texts, such as art, poetry, music and sacred architecture. It combines aspects of human experience and existence. As a result of integral evangelism, William (2000: 49), notes that "Spirituality must now touch every area of human experience, the public and social, the painful, negative even pathological by ways of the mind, the moral and relational world." Integral evangelism therefore provides a recreational platform for holistic transformation that builds and sustains reproductive relationships. Thus, an introduction of a model to enhance integral evangelism as a platform for Christian spirituality is hereby recommended.

\subsection{Integral Evangelism Model}

(i). If evangelism has to be approach in a comprehensive manner, the initial church stage is the introductory evangelism phase when converts are brought to Christ. At this point the new converts are at an infant stage. From Biblical point of view, they are compared like newly born children who do not know how to work (1 Peter 2:2). This stage may take from six to twelve months depending on the holistic and receptive nature of the church.

(ii). Body building period which is called the developing stage. At this level, the new Christians are discipled and mentored to become reliable, responsible and reproducible discipler themselves with a solid intentionality of having them take over leadership from older leaders.

(iii). Interdependent Church Stage: This stage allows quality opportunity for koinonia fellowship to exercises without discrimination (Acts 2:42-47). At this level, there is active participation within believers. Sider (2003:89), opines that "If Christians truly believe that people are spiritual beings as well as material beings; shouldn't we work at spiritual transformation at the same time work at physical transformation?" In view of what Sider pointed out in order to combine word and deed, those who bear witness in context of Africa are to take a careful audit of their proclamation and examine what they are really evangelizing. Are both evangelism and social ministry are going hand in hand?

(vi).The maturation stage takes place when both the spiritual and physical needs are handled (Acts 6). The gospel progresses and spiritual formation takes place through word and deed when integral evangelism is combined with actions of love, compassion and justice for all categories of people. These are inseparable dimensions of the one gospel. Integral evangelism create the concept of selfempowerment of new Christians as an important aspect of the mission of Christ. Integral evangelism does not encourage stereotype method of conservative conversion whereby only the spiritual is emphasized and leaving out the self-empowerment aspect. In powerful ways Christians in context of Africa today need to recover the model of integral evangelism as it was the practice Jesus introduced in Biblical times and the early church followed his example. The Anabaptists knew this in the sixteenth century when they began putting together word and deed. God can still use Christians, to heal and build up hurting people,; lead them to personal faith in Christ; transform society and glorify God using integral evangelism as a platform for Christian spiritual in contemporary Africa today. 


\section{REFERENCES}

[1] Abraham, W.J. The Logic of Evangelism. Grand Rapids, Michigan: Eerdmans Publishing Company, 1985.

[2] Adeney, M. Global Missiology for the $21^{\text {st }}$ Century. Grand Rapids, Michigan: Baker Book House, 2000.

[3] Bakke, R. The Urban Christian: Downers Grove: Intervarsity Press, 1987.

[4] Baumohl A.Making Adult Discipleship: Learning and Teaching in the Local Church Austria: Anzia Publishers, 1994.

[5] Bennell, RIntentional Discipleship. Colorado: Navpress, 2001.

[6] Bosch, D.J. Transforming Mission: Paradigm Shifts in Theology of Mission. Maryknoll, New York: Orbis Books, 1991.

[7] Broom, W. Guidelines for World Evangelism. Texas: Biblical Research Press, 1976.

[8] Brueggemann, W. Biblical Perspectives in Evangelism. Nashville: Abingdon Press, 1993.

[9] Costas, O. Liberating News: A Theology of Contextual Evangelization. Grand Rapids: Eerdmans Publishing Company, 1989.

[10] Escobar, S. A Time for Mission: The Challenge for Global Christianity. England: Intervarsity Press, 2003.

[11] Foster, R.J. Celebrations of Disciplines: The Path to Spiritual Growth. New York: HarperCollins Publishers, 1998.

[12] Gary, D. Looking God's Way: A Fresh Look at the One Another Passages. Columbus, Ohio: exons publishing, 1996.

[13] Greer, R. Origen: An Exhortation to Martyrdom, Prayer and Selected Works. New York: Paulist Press, 1979.

[14] Hestenes, R. Using the Bible in Groups. USA: Westminster Press, 1983.

[15] Hull, B. Discipleship Making Pastor. Grand Rapids, Michigan: Revell, 1988

[16] Hunter, G.G. Church for the Unchurch. Nashville, Abingdon Press, 1996.

[17] Klaiber, W. Call and Response: Biblical Foundation of a Theology of Evangelism. Nashville: Abingdon Press, 1991.

[18] McGavran, D. Understanding Church Growth. Grand Rapids: Eerdmans Publishing Company, 1990.

[19] McGrath, A. Christian Spirituality: An Introduction. Oxford: Blackwell Publishers, 1999.

[20] Michael, Certeau. The Post Modern God Edited Graham Ward, Oxford: Blackwell, 1997

[21] Neighbour, R. Where do We Go from Here? A Guide for Cell Group Churches. Houston: Touch Publications, 1990.

[22] Newbigin, L. The Open Secret: An Introduction to Theology of Missions. Grand Rapids: Eerdmans Publishing Company, 1995.

[23] Newbigin, L. Mission in Christ's Way. New York: Friendship Press, 1987.

[24] O’Brien, W.R. Global Good News: Mission in a New Context. Nashville: Abingdon Press, 2001.

[25] Ogden, G.Transforming Discipleship: Making Disciples a Few at Time Downers Grove: Intervarsity Press, 2003

[26] Ogden, G. The New Reformation: Returning the Ministry to the People of God. Grand Rapids Michigan: Zondervan, 1990.

[27] Palmer, T. Christian Theology in an African Context.Bukuru: Africa Christian Textbooks, 2015.

[28] Perkins, J.M. Restoring at Risk Communities. Grand Rapids,Baker Books, 2001.

[29] Posterski, D. Reinventing Evangelism: New Strategies for Presenting Christ in Today's World. Downers Grove: Intervarsity Press, 1989.

[30] Putman, W.J. Real Life Discipleship Manual. Carolado: Navpress, 2010.

[31] Sheldrake, P. Spirituality: A Brief History. Oxford: Welel-Blacwell, 2013.

[32] Sheldrake, P.Exploration in Spirituality: History, Theology and Social Practice. New York: Paulist Press, 2010.

[33] Schulz, K.D. Mission From the Cross. Saint Louis: Concordia Publishing House, 2009.

[34] Shenk, W. Exploring Church Growth. Grand Rapids: Eerdmans Publishing Company, 1983.

[35] Sider, R.J. Just Generosity: A New Vision for Overcoming Poverty in America. Grand Rapids: Baker Books, 2002.

[36] Sider, R.J. Doing Evangelism Jesus' Way: How Christians Demonstrate the Good News. Nappanee, Indiana: Evangel Publishing House, 2001. 
[37] Sterwart, C.F. African -American Church Growth: 12 Principles for Prophetic Ministry. Nashville: Abingdon Press, 1994.

[38] Stott, John. Making Christ Known. Grand Rapids: Eerdmans Publishing Company, 1997.

[39] Tucker, R.A. From Jerusalem to Irian Jaya: A Biographical History of Christian Missions. Grand Rapids: Zondervan, 1995.

[40] Underhill. E.Mysticism: The Nature and Development of Spiritual Consciousness Oxford: One world Publishers, 1993

[41] Wakatama, P. Independence for Third World Church: An African Perspective on Missionary Work. USA: Intervarsity Press, 1976.

[42] Walls, A.F. The Missionary Movement in Christian History. Maryknoll, New York: Orbis Books, 1996.

[43] Williams, R. Christian Theology. Oxford: Blackwell, 2000.

[44] William, R. The Wound of Knowledge: Christian Spirituality from the New Testament to St John of the Cross. London: Dayton Longman \& Todd, 1990.

[45] Willimon, W.H. Calling Character: Virtues of the Ordained Life. Nashville: Abingdon Press, 2000.

\section{AUTHOR'S BIOGRAPHY}

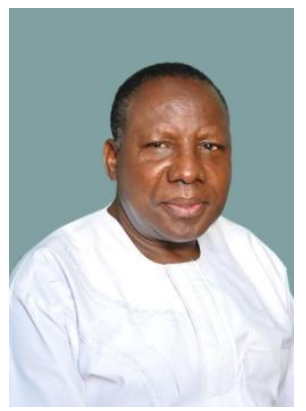

Associate Professor. Mipo E. Dadang, $\mathrm{PhD}$ has extensive experience in church leadership and theological education holding senior church posts within ECWA denomination at district level, in the Jos ECWA Theological Seminary (JETS) and latterly as General Secretary of ECWA for six years. He also set up and led Africa Services and was the first West Africa Director for Community Bible Study International (CBSI). After theological training in Nigeria and at Eastern University in Philadelphia he completed a Ph.D. from Concordia Theological Seminary, Fort Wayne, Indiana. Married with four children he is currently lecturing at JETS.

Citation: Mipo E. Dadang, PhD. "Integral Evangelism as Platform for Christian Spirituality in Context of Africa” International Journal of Humanities Social Sciences and Education (IJHSSE), vol 8, no. 6, 2021, pp. 37-48. doi: https://doi.org/10.20431/2349-0381.0806006.

Copyright: (C) 2021 Authors. This is an open-access article distributed under the terms of the Creative Commons Attribution License, which permits unrestricted use, distribution, and reproduction in any medium, provided the original author and source are credited. 